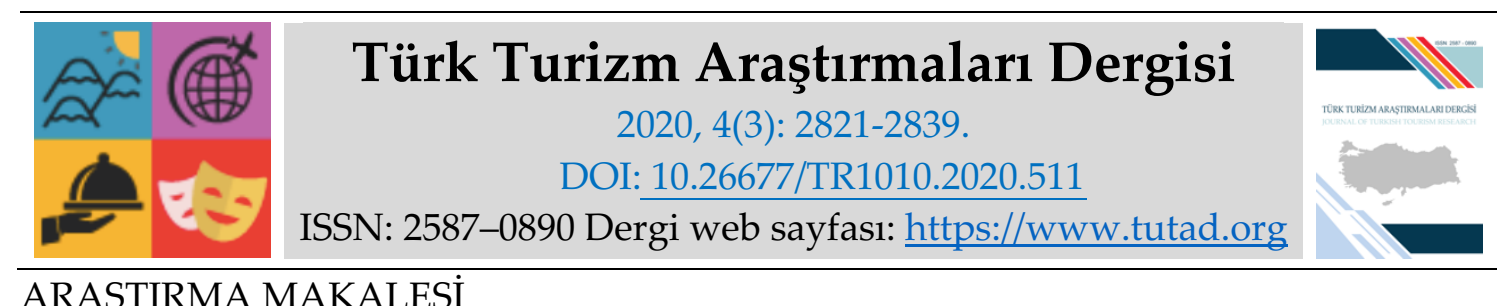

ARAȘTIRMA MAKALESI

\title{
Engelli Bireylerin Turizme Katılımına Yönelik Konaklama İşletmelerinden Beklentileri ve Mevcut Durum Tespitine İlişkin Bir Araştırma*
}

Doç. Dr. Aydın YILMAZER, Sakarya Uygulamalı Bilimler Üniversitesi, Turizm Fakültesi, Sakarya, e-posta: yilmazer@subu.edu.tr ORCID: https://orcid.org/0000-0001-8295-4745

Doç. Dr. Nur Ü. KALPAKLIOĞLU, Haliç Üniversitesi, İşletme Fakültesi, İstanbul, e-posta: nurundey@halic.edu.tr ORCID: https://orcid.org/0000-0003-3637-7240

Sena YILMAZ, Yüksek Lisans Öğrencisi, Haliç Üniversitesi, İşletme Fakültesi, İstanbul, e-posta: enayilmaz2006@hotmail.com ORCID: https://orcid.org/0000-0002-8120-7761

Öz

Araştırmanın amacı, engelli bireylerin turizm faaliyetlerine katılımına yönelik konaklama işletmelerinden beklentileri ve mevcut durum tespitine yönelik İstanbul ili üzerinden incelenmesidir. Bu amaca yönelik, 33 adet sorudan oluşan bir anket formu oluşturulmuştur. Üç bölümden oluşan bu anket formu, birinci bölümde demografik değişkenler, ikinci bölümde, konaklama işletmelerinden beklentileri, üçüncü bölümde ise engelli bireyler için konaklama işletmelerinin uygunluğunun mevcut durum tespitine yönelik ifadelerden ibarettir. Anket formu, İstanbul İli içerisinde ulaşılabilen 350 engelli bireye uygulanmıştır. Toplamda 350 anket ile istatistiki analizler yapılmıştır. Ölçek olarak Likert tipi 5'li ölçeklendirme kullanılmıştır. Anketler SPSS programı aracıllğıyla çözümlenmiş, frekans analizi yardımıyla sonuçlar yorumlanmıştır. Araştırma sonucunda, konaklama işletmeleri hakkında engelli bireylerin olumsuz düşüncesinin hâkim olduğu, işletmenin yapısı, hizmetleri, teçhizatı konusunda memnuniyet derecelerinin düşük seviyede görüldüğü tespit edilmiştir. Buna ilave olarak, engelli bireylerin turizme katılma niyetleri olsa da turizm hareketlerine katılım düzeylerinin düşük düzeyde olduğu sonucuna ulaşılmıştır.

*Yüksek Lisans Tezinden Geliştirilmiştir.

Anahtar Kelimeler: Engelli, Engelli Turizmi, Konaklama İşletmeleri, İstanbul.

Makale Gönderme Tarihi: 05.05.2020

Makale Kabul Tarihi: 07.07.2020

Önerilen Atıf:

Yılmazer, A., Kalpaklığlu, N. Ü. ve Yılmaz, S. (2020). Engelli Bireylerin Turizme Katılımına Yönelik Konaklama İşletmelerinden Beklentileri ve Mevcut Durum Tespitine İlişkin Bir Araştırma, Türk Turizm Araştırmaları Dergisi, 4(3): 2821-2839.

(C) 2020 Türk Turizm Araştırmaları Dergisi. 


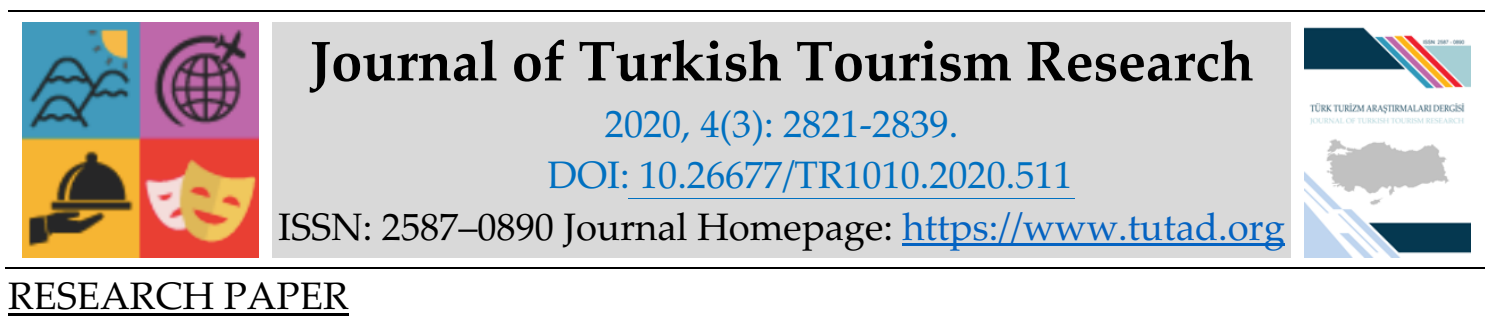

\title{
A Research on The Expectations of Disabled Individuals from Hospitality Enterprises for Tourism Participation and Current Situation Determination
}

Associate Prof. Dr. Aydın YILMAZER, Sakarya University of Applied Sciences, Faculty of Tourism, Sakarya, e-mail: yilmazer@subu.edu.tr

ORCID: https://orcid.org/0000-0001-8295-4745

Associate Prof. Dr. Nur Ü. KALPAKLIOĞLU, Haliç University, Faculty of Management, İstanbul, e-mail: nurundey@halic.edu.tr

ORCID: https://orcid.org/0000-0003-3637-7240

Sena YILMAZ, MSc., Haliç University Faculty of Management, İstanbul, e-mail: enayilmaz2006@hotmail.com

ORCID: https://orcid.org/0000-0002-8120-7761

\begin{abstract}
The aim of the research is to examine the expectations of individuals with disabilities from the hospitality establishments for their participation of tourism activities and for determining the current situation in İstanbul. A questionnaire form consisting of 33 questions has been created for this purpose. This questionnaire, consisting of three parts, consists of demographic variables in the first part, expectations from accommodation companies in the second part, and statements regarding the current situation determination of the suitability of accommodation enterprises for individuals with disabilities in the third part. The questionnaire form was applied to 350 disabled people who can be reached in Istanbul Province. Statistical analysis was made with 350 questionnaires in total. Likert type 5 scaling was used as the scale. The questionnaires were analyzed through the SPSS program, and the results were interpreted with the help of frequency analysis. As a result of the research, it has been determined that the negative opinion of the disabled individuals about the accommodation establishments is dominant, and the level of satisfaction about the structure, services and equipment of the enterprise is seen to be low. In addition, it was concluded that although the disabled individuals have intentions to participate in tourism, their level of participation in tourism movements is low.
\end{abstract}

Keywords: Disabled, Accessible Tourism, Hospitality Enterprises, İstanbul.

Received: 05.05.2020

Accepted: 07.07.2020

\section{Suggested Citation:}

Yılmazer, A., Kalpaklıoğlu, N. Ü. and Yılmaz, S. (2020). A Research on The Expectations of Disabled Individuals from Hospitality Enterprises for Tourism Participation and Current Situation Determination, Journal of Turkish Tourism Research, 4(3): 2821-2839.

(c) 2020 Türk Turizm Araştırmaları Dergisi. 


\section{Gíriş}

"Engellilik", herhangi bir kişinin diğer kişilere kıyasla sıradan sayılabilecek yaş, cinsiyet, sosyal ve kültürel faaliyette bulunma ya da etkileşime girme durumunu olumsuz etkileyen ya da kısıtlayan herhangi bir doğuştan eksiklik ya da daha sonra yaşanan bir sakatlığa sahip olma durumudur (Burcu 2007). Engellilik kavramı söylemleri zamanla, tıbbi ve kişisel söylemler ile toplumsal söylemlere evirilmiştir. Sonrasında ise bu söylemler, politikleşme geçirmiştirler. Bu sayede içsel bir ifade olan "özürlülük/sakatlık", dişsal bir ifade olan "engelliliğe" doğru evirilmiş ve sakat, özür, özürlü, sakatlık, özürlülük gibi benzeri ifadeler; 28636 sayılı ve 3.05 .2013 tarihli kanun ile kanun hükmünde kararnameler ile engelli kişilere dönük ifadeler değiştirilerek engelli, engellilik, engelli duruma gelen biçiminde düzenlenmiştir. Kalıtımsal veya sonradan farklı nedenlerle engelli olan bireylere sunulacak hizmetler, sadece engelli bireylerin değil, aynı zamanda başta yaşlı insanlar, hamile kadınlar ve çocuklar olmak üzere diğer normal insanların da faaliyetlere daha rahat ve kolay bir şekilde erişebilirliğini sağlayacak ve onların da yaşam kalitelerinin artmasına katkı sağlayacaktır. Medeni toplum oluşturulmasında, engelli bireylerin toplumsal hayata katılımının önündeki engellerin kaldırılması ve yaşamın tüm kesimlerine uyumlarının sağlanması önemli bir göstergedir. Sunulacak olan hizmetlerin belirlenmesi ve kriterlerinin sağlanmasında engelli ve engelli yakınlarının doğru bir şekilde ihtiyaç ve beklentilerinin değerlendirilmesi gerekmektedir (Akıncı ve Sönmez, 2015).

Herkes için erişilebilir bir şehirde bireylerin tamamı kendini güvende, özgür ve konforlu hissedebilir. Bütüne bakılarak, insan odaklı bakış açısıyla normal olarak adlandırılan bireylerin yanında hareket kısıtlılıkları da göz önünde tutulur ve herkes için erişilebilir tasarımlar yapılması durumunda şehir tüm toplum için kullanışlı, konforlu, ulaşılabilir ve ergonomik olması mümkündür. Herkes aynı derecede toplumsal alana erişim hakkına sahiptir. Bu alanlarda bulunan ulaşım araçları, binalar, kentsel donatılar, yollar kullanıcıyı ayırmaksızın hepsinin erişimine uygun dizayn edilmesi gerekmektedir. Bu sayede hareket kısıtlaması yaşayan kişiler; beraber yaşama ve sosyal hayata adapte olup katılma noktasında fırsat eşitliği yaşayacaktır.

Öte yandan, turizm endüstrisinde önemli bir yere sahip olan konaklama işletmelerinde engelli bireylerin turizm aktivitelerine katılımını engellemekte olan birçok olumsuz unsur mevcuttur. Bunların başında ise konaklama işletmelerinin iç ve dış çevre yapısı yani fiziki bariyer ile bireylerin içerisinde bulunduğu ruhsal durumları gelmektedir. Fiziki bariyerlerin başında konaklama işletmelerine giriş, odalar, havuz, lavabolar vb. yerlerin dizaynı ve finansal bariyerler gelmektedir. Gerekli şartlarla düzenlemeler yapılsa bile finansal problemler nedeniyle engelli bireyler turizmden istenen düzeyde faydalanamayacaktır. Finansal sıkıntıların ardından ise turizmdeki ilk adım olan ulaşım ile ilgili sıkıntılar fiziki engellerin arasındadır. Fiziki bariyerlerden bir diğeriyse, çevresel tasarımdaki standartların engellilere uygun olmamasıdır. $\mathrm{Bu}$ kapsamda araştırma, engelli bireylerin turizm faaliyetlerine katılımındaki konaklama işletmelerinden beklentileri ve mevcut durum tespitine ilişkin İstanbul ili örneği incelenmiştir. Ayrıca, yapılan literatür incelemesinde engelli bireylerin turizme katılımına yönelik sınırlı sayıda çalışmaya rastlanması bu konuda bilimsel yayınların yapılmasının gerekliliğini ve önemini ortaya koymaktadır.

\section{KAVRAMSAL ÇERÇEVE}

\section{Engellilik Kavramı ve Çeşitleri}

Engellilik kavramı, herhangi bir bireyin diğer bireylere kıyasla sıradan sayılabilecek yaş, cinsiyet, sosyal ve kültürel faaliyette bulunma ya da etkileşime girme durumunu olumsuz etkileyen ya da kısıtlayan herhangi bir doğuştan eksiklik ya da daha sonra yaşanan bir sakatlığa sahip olma 
durumudur (Burcu, 2007). 28636 sayılı ve 3.05.2013 tarihli olan Resmi Gazetesi'nde yayınlanmıştır. 6462 sayılı ve kabul tarihi 25.4.2013 olan, kanun ile KHK'lerde yer almış olan engelli kişilere dönük ibarelerin değiştirilmesi maksadıyla bazı kanunlar ve de KHK'lerde değişiklikler yapılmıştır. İlgili kanun bağlamında, sakat, özür, özürlü, sakatlık, özürlülük ve sakatlanan benzeri ifadeler; engelli, engellilik, engelli duruma gelen biçiminde düzenlenmiştir. (Seyyar, 2006: 17; Resmi Gazete, 2013). Engelli veya Özürlü şeklinde adlandırılan kavramlar ADA (The Americans With Disabilites Act), Amerikan Engelliler Kanunu'nda da düzenlenmiştir. Buna göre, özürlü kavramı yalnızca bedensel ve psikolojik rahatsızlıkları değil, bunların yanında toplumsal suçlardan meydana çıkmış olan sınırları da ihtiva etmektedir (Sezgin ve Ünüsan, 2007). Ayrıca, engellilik kavramı geçmişte, "fiziksel, ruhsal ve zihinsel yapısında belli miktarlarda fonksiyonel yitimine neden olan, organların yokluğu ve de bozukluğu sonucunda sosyal rollerini icra edebilmesi adına rehabilitasyon, bakım, danışmanlık ve de destek hizmetlerine gereksinimi olan kimse şeklinde ifade edilirken (Seyyar, 2006) günümüzde, "doğuşsal olan ya da daha sonraları herhangi bir kazanın ya da hastalığın neticesinde fiziksel, duyuşsal, duygusal, ruhsal ve de sosyal yeterliliklerini belirli oranlarda yitirmesi sebebiyle normal yaşam gerekliliklerine uymama halinde olup; bakım, korunma, rehabilitasyon, danışmanlık ile destek hizmetlerine gereksinimi bulunan kimse biçiminde ifade edilmektedir (Seyyar, 2006). Engelli vatandaşlarımızın sıkıntı ve sorunlarını tespiti ve bu tespitlerin uygun bir biçimde kapsamlı olarak düzgün bir etki veya politika oluşturabilmek adına 2002'de gerçekleştirilen Türkiye Özürlüler Araştırması'nda engelli kişiler altı grup altında incelenmiştir. Bu grupları sıralayacak olursak; (Şahin, 2012; Ketboğa, 2016; Coşkun, 2010).

Bedensel engelliler; bedensel bir engel olarak kabul edilen ortopedik engellilik, kişinin hareketlerini gerçekleştirebilmesini, çalışabilmesini ve fiziksel engellemelerden dolayı çevresine uyum sağlayabilmesini zorlaştıran engellilik grubunu oluşturmaktadır (Artar ve Karabacakoğlu 2003: 13). Fiziksel ya da ortopedik engelli, iskelet ve kas sistemindeki yetmezlik, bozukluk ve fonksiyon yitimi bulunan şahıstır. El, kol, ayak, bacak, parmak ve de omurgalarda; eksiklik, kısalık, fazlalık, hareket eksikliği, şekilsel bozukluk, kaslarda güçsüzlük ve kemik hastalıkları olanlar, beyin felçliler ve felçliler, spastikler bu engel grubunda bulunmaktadır (Şahin, 2012; Ketboğa, 2016).

Zihinsel engelliler; sosyal yaşamda çoğunlukla yanlış bir değerlendirme ile 'deli' veya 'geri zekâlı' olarak nitelendirilen zihinsel engelliler, aslında hayatları boyunca belli bir zekâ seviyesinde kalan fakat belirli bir algılama yetisine sahip kişilerdir (Ören 2003: 128). Kişinin gündelik yaşamında gereksinimlerini olması gerektiği gibi yerine getirmesini zorlaştıran ve engelleyen eksikliklere ve yetersizliklere verilen genel isimdir. $\mathrm{Bu}$ engelli bireylerin engel durumları birçok farklı seviyede ve biçimlerde seyredebilmektedir. Zekâ geriliği bulunanlar (mental-retardasyon), Fenilketonüri (zekâ geriliğine yol açmışsa), Down Sendromlu olanlar bu engel grubuna girerler (Şahin, 2012; Ketboğa, 2016).

Görme engelliler; bireyin bilgi ve deneyimleri açısından oldukça önemli bir özelliktir (Öngören vd., 2007: 28). Çünkü birey gündelik yaşamında diş dünyan ile bilgi alışverişini ve etkileşiminin $\% 85$ 'ini görsel olarak gerçekleştirdiği bilinmektedir. Kişinin bu engelli grubuna girmesi için görme kaybı, renk körlüğü, gece körlügü veya göz protezi kullanması yeterlidir. Görme engeli sadece doğuştan gelen bir engel değildir sonradan da ortaya çıkabilmektedir (Coşkun, 2010).

İşitme engelliler; İşitme engeli de, bu bozukluklar sonucu, işitme fonksiyonlarında çeşitli derecelerde hasar oluşması ve işitme kaybı yaşanması şeklinde oluşmaktadır (Öngören vd., 2007: 23). İşitme engeli en az bir kulak için ortaya çıkan işitme kaybı veya tamamıyla işitmeme halidir. Duyma yetisinin kısmi ya da tamamıla yetmezliği sonucu konuşma becerileriyle iletişim yetilerinde zorluk oluşması sebebiyle kişinin eğitim sürecinin ve sosyal uyum sürecinin negatif etkilenmesi durumu olarak açıklana bilmektedir (Öztürk, 2011). 
Dil ve de konuşma engelliler; kişilerarası etkileşimde büyük bir önem taşıyan sözel iletişim için dil ve konuşma kazanımının gerektiği bilinmektedir. Farklı sebeplerle konuşamayan ya da konuşmasının akıcıllı̆ııda, süratinde, ifade biçiminde sıkıntılar bulunan ve de ses bozukluğuna sahip kişilerdir (Ketboğa, 2016). İşittiği halde konuşamayanlar, konuşabilme adına alet kullananlar, gırtlağı alınmış olanlar, kekemeler, afazi, dudak-damak-dil ve de çenesinde yapısal bozukluklar olanlar bu gruptadır (Öztürk, 2011).

Daimi (sürekli hastalığı olanlar); Bireyin çalışabilmesine veya yaşam sürmesine engel olan, devamlı tedavi ve bakım gerekli kılan, bireylerin hayati işlevlerini etkileyen ve engelleyen farklı düzeylerde iş gücü kaybı yaşatan ve başka kimselere bireyi bağımlı hale getiren bütün rahatsızlıklar bu bağlamda incelenebilir (Öztürk, 2011; Öngören vd., 2007: 7). Kısaca geçirmiş olduğu bir hastalık nedeniyle tam olarak tedavi edilemeyen bireyler, söz konusu hastalık ya da hastalığın bıraktığı izlerle yaşamlarına devam etme durumudur. Bu tür hastalıklara daimi adı verilmekte ve kavram hakkında çeşitli açılamalar getirilmektedir (Çakan ve Sezer, 2010: 162). Literatürde, daimi hastalıklar başlığı altında ele alınan çok geniş bir yelpazeyi kapsadığı görülür. Bunlar, psikolojik rahatsızlıklar, ruhsal davranış bozukluğu olanlar, verem, kanser, ateşli romatizma, nefrit, felç, kalın ve ince bağırsak iltihabı, astım, karaciğer iltihabı, alerjililer, bozuk beslenme, ileri düzey şeker hastaları şeklinde sıralamak mümkündür. (Aslan, 2011: 452; Şahin, 2012).

Diğer engelliler; diğer engel grupları olarak, uyum güçlüğü olanlar, öğrenme güçlüğü olanlar, otistik engelliler, down sendromuna sahip olanlar, üstün zekâlılar ve üstün yetenekliler ele alınmıştır. Uyum güçlüğü olanlar; saldırgan, dışa dönük, asabi, halüsinasyonlar gören, okuldaki çalışmalara ilgisiz, hareketli, sakin, içe dönük, utangaç tavırlarda bulunurlar (Şahin, 2012). Uyumsuz davranışlar gösteren çocuklar 5 kategoride gösterilebilir. (Şahin, 2012; Özsoy, 1998) Bunlar; A-sosyal davranışlar gösteren çocuklar, Alışkanlıklarla eğitim hususunda sorunlar görülen çocuklar, Emosyonel gelişimleriyle ilgili sorunlar yaşayan çocuklar, Seks sorunu bulunan çocuklar, Gelişim ile ilgili sıkıntıları bulunan çocuklardır.

Engelli bireylerin toplum içindeki yerine bakıldığında, Dünya sağlık örgütünün 2013 yılı verilerine göre, dünya üzerinde yaklaşık bir milyarın üstünde engelli birey mevcut olduğu belirlenmiştir. Bu veriler incelendiğinde dünya üzerindeki nüfusun yüzde 15 'inin engellilerden oluştuğu manasına gelmektedir (Zengin, 2013). Aynı veriler doğrultusunda Avrupa ülkelerinin arasında en çok engelli nüfusuna sahip ülkelerse; Almanya, Fransa, Türkiye ve de İtalya şeklinde gösterilmiştir (Bulgan, 2014). Dünya sağlık örgütü insan toplumunun minimum yüzde onunun engellilerden oluştuğunu belirtmektedir. Avrupa'da hamileler ve de yaşlılarla beraber toplam sayının elli milyonun üstüne çıkmış olduğu tespit edilmiştir (Zengin, 2013). Türkiye'deki engelli yurttaşlar aileleri ve de yakınları ile beraber yirmi milyon civarı bir potansiyeli oluşturmaktadırlar (Ünüsan ve Sezgin, 2007). AB üyesi olan ülkelerin içerisinde Finlandiya yüzde $32,2^{\prime}$ lik oran ile yüzdesel olarak en yüksek engelli nüfus oranına sahip ülkedir. Fakat en çok engelli nüfus ise 17 milyon kişiyle İngiltere'dedir. İngiltere bu sebeple engellilere yönelik yasalar ve düzenlemeler oluşturmuştur (Zengin, 2013).

Ülkemizde engelli kişilerin sorun, ihtiyaç ve beklentileri üzerine ilk araştırmalara 2010'da Özürlülerin Sorun ve Beklentileri Araştırması adlı çalışmasıyla TÜiK gerçekleştirmiştir. Ülkemizde engelli birey sayısı 2002' de Başbakanlık Özürlüler İdaresi Başkanlığı'nın, Başbakanlık Devlet İstatistik Enstitüsü'yle yürütmüş bulunduğu araştırmalar sonucunda yaklaşık olarak nüfusun yüzde 12.29'unu oluşturduğu tespit edilmiştir. Bu verilere göreyse Türkiye'de engelli olan 9.181.679 (\%12.29) kişinin \%7.092'si erkekler, \%5.022'si de kadınlardan oluşmaktadır. Ülkemizde TUIK, 2010 verilerine göre engellilerin engel türlerine göre dağılımı ise şu şekildedir. Yüzde olarak daimi hastalık; 25,5, Ortopedik; 8,8, Görme; 8,4, İşitme; 5,9, Dil ve Konuşma; 0,2, Zihinsel; 29,2, ruhsal ve duygusal; 3,9 ve son olarak birden fazla özürlüler; 18'dir (TUIK, 2010: 2). 


\section{Engelli Turizm Kavramı}

Engelli bireylerin tek başına veya bir refakatçiyle turizm faaliyetlerine katılabilmeleri, bireysel ve sosyal bir gereksinim olarak görülmektedir. Engelli turizmi güçlenerek büyüyen ve gelişen bir olgu olmasına rağmen, bir bakıma hâlâ nadir olma özelliği taşımaktadır (Popie, 2014: 55). Oysaki engelli bireylerin toplumdan izole olmasının önüne geçilip toplumun bir parçası olmalarına imkân vermek gerekmektedir bunun için engelli bireylere yaşanılan mekânda ulaşılabilirliğini de sağlamak gerekmektedir. Ulaşılabilirlik; insan tarafından inşa edilmiş hangi bina ya da yapılmış yapı olursa olsun herkes tarafından erişilebilirliğe açı olmalı ve kullanılabilir olması gerekmektedir. Erişilebilirlikten kasıt ise, herhangi bir bireyin yol, bina, giriş ve diğer dış mekân faaliyetleriyle özel ihtiyaçları adına tasarlanmış olan düzenlemelerdir (Seyyar, 2006). Engelli turizm ile ilgili pek çok tanım yapılmıştır. En genel tanımı ise şöyledir; engelli turizmini, bedensel, görme, dil, konuşma, işitme ve zihinsel açıdan engele sahip bireylere yönelik gerçekleştirilen turistik ürün, hizmet ve faaliyetlerini kapsayan turizm çeşidi olarak ifade etmek mümkündür (Tozlu ve Atay, 2011: 606).

Dünya Turizm Örgütü, 1999'daTurizmde Global Etik İlkeler Bildirgesi'ni yayınlamıştır. Bu bildirge dâhilinde, turizm faaliyetleri insan haklarına, hususiyetle de engelli, çocuk, yaşlı, azınlıklar benzeri daha savunmasız kitlelerin kişisel haklarının gelişimi, engelli bireylerin hakları teminat altına alınmış ve turizme katılmaları kolaylaştııılmıştır (Westcott, 2004). Ülkemizde de 21.06.2005 tarihinde Resmi Gazete'de yayınlanarak yürürlüğe giren yönetmelikte, Asli Konaklama Tesislerinin Genel Nitelikleri başlıklı 18. Maddesinde, engelliler adına düzenlemelere yer verilmiştir. Oda kapasitesi seksen ve üstünde olan otellerle tatil köylerinde minimum bir oda olmak şeklindedir. Toplamdaki oda sayısını yüzde biri seviyesinde odada ise, yine tesisin girişinde, mola noktaları, genel tuvaletlerle minimum bir adet olması gerekli kılınmış ve yeme içme biriminde, temalı parklarla eğlence merkezlerinde de kendi türlerindeki minimum niteliklerinde gerekli şekilde engellilerin kullanımına uygun olan ilgili düzenlemeler yapılmıştır (Subaşığlu, 2008; Zengin, 2013). Ayrıca, 15.06.2006 tarihinde herkes için engelsiz turizm komitesi TÜRSAB bünyesinde kurulmuştur. Kuruluş amacl; turizm potansiyelinin engelliler pazarına sunmuş olduğu ürünleri ve yaşanan sıkıntıları tespit etmek, yerli ya da yabancı engelli bireylerin engelsiz şekilde seyahatlerini ve erişilebilirliklerini sağlamaktır (TÜRSAB, 2008).

Bireylerin geceleme gereksinimini, değişik yerlerde karşılayabilme özelliğini taşımakta olan yapılar konaklama işletmeleri şeklinde tarif edilir (Akat, 2008).Turizm endüstrisinin konaklama işletmelerinde engelli turizme yönelik olması gerekenleri ayrıntılı şekilde belirtilecek olursa, (Artar, 2003) Otoparklarda yapılması gereken düzenlemeler, rampalarda yapılması gereken düzenlemeler, basamak ve merdiven, ana giriş kapıları, lobi, resepsiyonda yapılması gereken düzenlemeler, telefonlar, tuvaletler, lavabolar, asansör, koridor giriş terleri, yeme-içme alanları, yürüyüş yolları, havuz, toplantı yerleri, rekreasyon alanları, sauna, hamam, plaj, engelsiz iç mekanlar (odalar, İşaretler, bilgilendirme ve tabelalar), erişilebilir mevzuat odanın imkanları (engellilere ayrılan odaların ilk katta bulunması, kolayca kullanılan kapılar, asansöre mesafe gibi.) ve banyo imkanları (duştaki oturma yeri, tutunma barı, kaymayan zemin gibi.) engelli turistler adına önem arz etmektedir (Ayyıldız, 2014; Tozlu ve Atay, 2011).

\section{Engellilerin Turizm Faaliyetlerine Katılmalarını Engelleyen Faktörler}

Yerli ve yabancı kaynaklar incelendiğinde; (Westcott, 2004); (Buhalis, 2010); (Davies, 1994); (Yau, 2004); (Ayyıldız, 2014); (Tozlu ve Atay, 2011); (Ünüsan ve Sezgin, 2007); (Akat, 2008). Engellilere konaklama işletmeleri ve seyahat acentelerinin güvenilir bilgiler sunmadığı, yine engelli bireylerin ihtiyaçlarına uygun bulunmayan mimari, ulaşım vasıtaları ve otellerin varlığı, eğitimli 
olmayan çalışanların engelli bireylerin turizme dahil olmalarını negatif yönde etkilediği görülmektedir. Engelli bireylerin turizm aktivitelerine katılımını engelleyen faktörlerin ise genelde benzer olduğu ifade edilmektedir. Bu çerçevede engelli turizmi ile ilgili yapılan çalışmalar, bu sektörü oluşturan seyahat acenteleri, otellerin ve de ulaşımın engelli bireylere sundukları hizmetlerdeki noksanlıkların diğer bir söyleyişle sorunların, onların turistik faaliyetlere katılmalarını negatif şekilde etkilediğini göstermektedir (Yau, 2004; Westcott, 2004; Yaylı, 2006; Buhalis, 2010). Bu kapsamda, yeterli olmayan yapı veya fiziki standartlar, politikalar, hizmetlerin yetersizliği, olumsuz olan tavırlar, tutumlar ve davranışlar, yetersiz mali güç ve yetersiz ulaşılabilirlik, iletişim araçlarının uygun olmaması, danışma ve de katılımın azlığı, verilerle bulgulardaki yetersizlik, sorun yaşayan engelli turistlerin başvurabilecekleri özel mercilerle mekânların olmaması gibi faktörler, engellilerin turizm aktivitelerine katılımını azaltan ya da zorlaştıran faktörler olarak söylemek mümkündür (Buhalis, 2010; Yau, 2004). Bu olumsuz faktörlerin ortadan kaldırılması için toplumun her bir bireyine ve tüm kuruluşlara büyük görevler düşmektedir. Çünkü her bireyde olduğu gibi engelli kimselerin de seyahat edip ve turistik faaliyetlere katılım göstermeleri en doğal haklarıdır. Turistik faaliyetler engelli ya da engelli olmayan her birey adına önemli ve gereklidir.

\section{YÖNTEM}

$\mathrm{Bu}$ araştırma ile engelli bireylerin turizm faaliyetlerine katılımına yönelik konaklama işletmelerinden beklentileri ve bu işletmelerin mevcut durumun tespiti amaçlanmaktadır. Bu kapsamda, araştırmanın evreni, İstanbul ilinde yaşayan engelli bireylerdir. Dolaysıyla elde edilen veriler araştırma evreni ile sınırlıdır. Araştırmada veri elde etmek amacıyla anket formu kullanılmıştır. İstanbul'da faaliyet gösteren sivil toplum kuruluşlarından destek alınarak, 350 engelli bireye ulaşılmıştır. Yani araştırma örneklemi 350 kişiden oluşmaktadır. Araştırmanın amacına yönelik, 33 adet sorudan oluşan bu anket formu, üç bölümden oluşmaktadır. Birinci bölümde demografik değişkenler, ikinci bölümde, konaklama işletmelerinden beklentileri (1'den-11'e kadar olan sorular), üçüncü bölümde ise engelli bireyler için konaklama işletmelerinin uygunluğunun mevcut durum tespitine (12'den 33'e kadar olan sorular) yönelik ifadelerden ibarettir. Analiz olarak güvenilirlik analizi, frekans analizi ve katılımcların demografik özellikleri ile konaklama işletmelerinden beklentileri ve mevcut durum tespitine yönelik görüşler arasında anlamlı bir farklılık olup olmadığını tespit etmek için de Mann Whitney U Testi analizi yapılmıştır. Ölçek olarak Likert tipi 1=kesinlikle katılmıyorumdan, $5=$ kesinlikle katılıyorum şeklinde 5'li ölçeklendirme kullanılmış, SPSS programı aracılığıyla çözümlenmiş ve frekans analizi yardımıyla sonuçlar yorumlanmıştır. Veriler toplandıktan sonra, oluşturulan ölçeğin güvenilirliği test edilmiştir. Araştırmada kullanılan ölçeğe yönelik yapılan doğrulayıcı faktör analizi ile güvenilirlik analizi sonucunda elde edilen bilgiler belirtilmiştir. Algılanan engelli bireylerin beklentilerine yönelik ölçeğin faktör yüklerinin $(, 612)$ ile $(, 837)$ arasında değerler aldığı tespit edilmiştir. Alfa katsayısına bakılarak ölçeğin güvenilirliği şöyle yorumlanmaktadır (Kalaycı, 2009; 405). Alfa katsayısına bakılarak ölçeğin güvenilirliği şöyle yorumlanmaktadır (Kalaycı, 2009: 405); , $80 \leq \alpha<1,00$ Aralığında ise ölçeğin yapısı yüksek derece güvenilir, $60 \leq \alpha<, 80$ Aralığında ise ölçek yapısı oldukça güvenilir, $40 \leq \alpha<, 60$ Aralığında ise ölçeğin yapısı düşük derece güvenilir, $00 \leq \alpha<0,40$ Aralığında ise ölçek güvenilir olmayan yapıdaki ölçektir. Dolaysıyla Tablo 1'de görüleceği üzere ifadelere ait Cronbach Alpha değerlerinin ölçeğinin güvenilir olduğunu göstermektedir.

Sonrasında basıklık ve çarpıklık etkileri incelenerek verilerde dağılımın normallik gösterme durumunu anlamak amaçlanmıştır. Değerlerin olması gereken sınır değerler arasında bulunduğu kararına varılıp katılımcıların algılanan beklentilerine ait olan ölçeğin normal dağılım 
koşuluna uygun olduğu (Kline, 2011) kabul edilerek, parametrik yapıda olan testleri uygulamaya karar verilmiştir.

Tablo 1: Engelli Bireylerin Beklentilerine Yönelik Ölçeğin Güvenilirlik İstatistiği Sonuçları

\begin{tabular}{ccccc}
\hline Cronbach's Alpha Değeri & St. Öğelere Göre Cronbach's Alpha Değeri & KMO & Bartlett & N \\
\hline, 812 &, 812 &, 836 & 799,843 & 11
\end{tabular}

\section{BULGULAR}

Araştırma bulguları dört kısımdan oluşmaktadır. Birinci kısımda katılımcıların demografik özelliklerine ilişkin frekans analiz sonuçları verilmektedir. İkinci kısımda, katılımcıların konaklama işletmelerinden beklentilerine yönelik soruların frekans analiz sonuçları tespit edilmiştir. Üçüncü kısımda, katılımcıların konaklama işletmelerinin mevcut durum tespitine yönelik görüşlerin frekans analiz sonuçları verilmektedir. Dördüncü kısımda ise, katılımcıların demografik özellikleri ile konaklama işletmelerinden beklentileri ve mevcut durum tespitine yönelik görüşler arasında anlamlı bir farklılık olup olmadı̆̆ı tespiti yapılmıştır.

\section{Demografik Özelliklerin Frekans Analizi Sonuçlanı}

İlk olarak 350 engelliye sorulan demografik özelliklerin frekans analiz sonuçları aşağıdaki tablolarda verilmektedir ve sonuçlar engellilerin durumlarını ortaya koyma yönünde yorumlanmaktadır.

Tablo 2. Demografik Bilgilerinin Frekans ve Yüzdelik Dağılımı

\begin{tabular}{|c|c|c|c|c|c|c|c|}
\hline \multicolumn{2}{|c|}{ Değişkenler } & (f) & (\%) & \multicolumn{2}{|c|}{ Değişkenler } & (f) & $(\%)$ \\
\hline \multirow{3}{*}{ Cinsiyet } & Kadın & 100 & 28.6 & \multirow{6}{*}{ Yaş } & 25 yaş ve altı & 22 & 6.3 \\
\hline & Erkek & 250 & 71.4 & & 26-30 Yaş & 30 & 8.6 \\
\hline & Toplam & 350 & 100.0 & & 31-35 Yaş & 28 & 8.0 \\
\hline \multirow{4}{*}{$\begin{array}{c}\text { Medeni } \\
\text { Durum }\end{array}$} & Evli & 146 & 41.7 & & 36-40 Yaş & 50 & 14.3 \\
\hline & Bekâr & 142 & 40.6 & & 41-46 Yaş & 58 & 14.6 \\
\hline & Eşinden Ayrı & 62 & 17.7 & & 46 yaş ve üstü & 162 & 46.3 \\
\hline & Toplam & 350 & 100.0 & & Toplam & 350 & 100.0 \\
\hline \multirow{11}{*}{$\begin{array}{l}\text { Eğitim } \\
\text { Durumu }\end{array}$} & İlkokul & 174 & 49.7 & \multirow{11}{*}{$\begin{array}{c}\text { Çalışma } \\
\text { Durumlarının/ } \\
\text { Mesleklerinin } \\
\text { Dağılımı }\end{array}$} & Çalışacak & & \\
\hline & Lise & 138 & 39.4 & & Durumda & 48 & 13,7 \\
\hline & Meslek & 20 & 5.7 & & Degil & 78 & 22,3 \\
\hline & Yüksekokul & 12 & 3.4 & & Serbest & 16 & 4,6 \\
\hline & Yuksekokul & 4 & 1.1 & & Esnaf & 40 & 11,4 \\
\hline & Fakülte & 2 & 0.6 & & İşsiz & 6 & 1,7 \\
\hline & Lisansüstü & & & & Öğrenci & 32 & 9,1 \\
\hline & \multirow{4}{*}{ Toplam } & \multirow{4}{*}{350} & \multirow{4}{*}{100.0} & & Ev Hanımı & 90 & 25,7 \\
\hline & & & & & Emekli & 12 & 3,4 \\
\hline & & & & & $\begin{array}{c}\text { Memur } \\
\text { Diğer }\end{array}$ & 28 & 8,0 \\
\hline & & & & & Toplam & 350 & 100.0 \\
\hline
\end{tabular}

Tablo 2' de görüldügüü üzere, anket çalışması uygulanan 350 engelliden 100 tanesi bayan iken, 250 tanesi erkektir. Engellilerin \%71,4'nu erkekler oluşturmaktadır. Ankete katılan 350 engelliden $\% 46,3$ 'u yani 162 tanesi 46 yaş ve üstündedir. Bunu \%16,6 ile 41-46 yaş arasındaki kişiler 
oluşturmaktadır. Ankette katılan \%6,3'u yani sadece 22 tanesi 25 yaş ve altıdır. Engellilerin medeni durum dağılımına bakıldığında, \%41,7'si evli, \%40'6 ise bekâr olduğu anlaşılmaktadır. Yine Tablo 2' de, ankete katılan engellilere eğitim durumları sorulmuştur ve \%49,7'si yani 174 kişi ilkokul mezunu iken, \%39,4'u ise lise mezunudur. Engellilerin üniversite eğitimi alanların sayısının çok az olduğu gözlemlenmektedir. Üniversite mezunu (4 yıllık) sadece 6 tanedir ve son olarak engellilerin mesleklerine yönelik bir soru sorulmuştur. Ankete katılan kişilerden \%13,7'si çalışacak durumda değil iken, 25,7'si emekli olduğu görülmektedir. \%22,3 yani 78 kişi ise serbest meslek ile uğraştı̆̆ını beyan etmişlerdir.

Tablo 3. Engelli Bireylerin Daha Önce Turizm İşletmelerine Gidip Gitmeme Durumuna Yönelik Frekans Analiz Sonuçları

\begin{tabular}{|l|c|c|}
\hline Konaklama İşletmelerine Gitme Durumu & (f) & (\%) \\
\hline Evet & 350 & $(100.0)$ \\
Hayır & 0 & 0 \\
\hline Toplam & 350 & $(100.0)$ \\
\hline
\end{tabular}

Tablo 3'de engelli bireylerin daha önce konaklama işletmelerine gidip gitmediği konusunda belirttikleri görüşlere göre örneklemin tamamı "evet" cevabı verdiği görülmüştür ( $f=350)$. Bu sonuç; araştırmaya katılan engelli bireylerin tamamının daha önceden bir otel işletmesinde konaklama imkânını bulmuş olmasını göstermesi bakımından önemlidir.

\section{Engellilerin Turizm İşletmelerinden Beklentilerine Yönelik Frekans Analizi Sonuçları}

Demografik sorulara ek olarak, engelli bireylerin turizm işletmelerine yönelik beklentilerinin neler olduğunun ortaya konulması amacıyla ilgili sorular sorulmuştur. Verilen cevaplar ise Likert ölçeğine göre, (1) Kesinlikle katılmıyorum, (2) Katılmıyorum, (3) Kararsızım, (4) Katılıyorum, (5) Kesinlikle Katılıyorum şeklinde alınmıştır.

Tablo 4' de Engellilerin turizm işletmelerinden beklentilerine yönelik frekans analizi sonuçlarına göre; turizm işletmelerinde engellilere özel olarak tasarlanan odaların yöneticilerin inisiyatifine bırakılması gerekmekte midir sorusuna \%65 katılımcı kesinlikle katılmaz iken, \%54'de katılmadığı, turizm işletmelerinin engelliler için sundukları teşvik ve promosyonlar sunmalı mı sorusuna, 350 kişiden 204 tanesi yani \%58'i bu tarz teşvik ve promosyonu çok isterken, 108 kişi (\%30)'de uygun bir düşünce olduğunu onayladığı, engelliler için tasarlanan oda sayısının artması gerektiği konusunda büyük çoğunluk 'kesinlikle katılıyorum' ve 'katıllyorum' diyerek, toplamda kişi bu soruya olumlu cevap verdiği anlaşılmaktadır.

Engelli bireylerin işletme personellerinden yardım konusunda istekli ve hevesli olmaları gerektiğini belirtmişlerdir. Toplamda 350 kişiden oluşan anket ana kütlesinden 340 kişi, işletme personelinin engelli bireylere yardımcı olmaları gerektiğini vurgulamaktadırlar. Yine Tablo 4 'de, konaklama işletmelerinin engellilere sundukları hizmetler hakkında tam olarak bilgilendirmeye sahip olması gerektiğine $\% 94,8$ kişi kesinlikle katılıyorum ve katılıyorum şeklinde cevap verdiği görülmektedir. Konaklama işletmelerinde çalışanların engellilere yardımcı olmak amacıyla özel eğitim almaları gerektiğini hemen hemen tamamı (336) kişi katılıyorum şeklinde beyan ettikleri anlaşılmaktadır. İşletmelerin odalarının teçhizatı ve standardı engelli bireylere kesinlikle uygun olması gerektiğini belirtenler \%59,4 iken, ilginç olarak katılmayan kişi sayısı ise sadece 2 olduğu, 
işletmelerin sosyal kullanım alanlarının ve ergonomik şartların engellilere uygun olması gerektiğini düşünen engelli birey sayısı oldukça fazla olduğu görülmektedir. Toplamda, olumlu gören kişi sayısı 330 kişi iken, olumsuz gören kişi sayısı ise 10'dur.

Tablo 4. Engellilerin Turizm İşletmelerinden Beklentilerine Yönelik Frekans Analiz Sonuçları

\begin{tabular}{|c|c|c|c|c|c|c|}
\hline Sorular & $\begin{array}{l}\text { (1) } \\
\text { F } / \%\end{array}$ & $\begin{array}{l}\text { (2) } \\
F / \%\end{array}$ & $\begin{array}{l}\text { (3) } \\
F / \%\end{array}$ & $\begin{array}{l}\text { (4) } \\
\text { F / \% }\end{array}$ & $\begin{array}{l}\text { (5) } \\
F / \%\end{array}$ & $\begin{array}{l}\text { Toplam } \\
\text { F / \% }\end{array}$ \\
\hline & 18 & 40 & 54 & 108 & 130 & 350 \\
\hline $\begin{array}{l}\text { Turizm İşletmelerinde Engellilere Özel Olarak } \\
\text { Tasarlanan Odaların Yöneticilerin İnisiyatifine }\end{array}$ & $(5.1)$ & $(11.4)$ & $(15.4)$ & $(30.9)$ & $(37.1)$ & $(100.0)$ \\
\hline Bırakılmaması Gerekmektedir? & 22 & 12 & 4 & 108 & 204 & 350 \\
\hline Turizm İşletmelerin Engelli Bireylerin Tatil & (6.3) & (3.4) & (1.1) & $(30.9)$ & $(58.3)$ & $(100.0)$ \\
\hline $\begin{array}{l}\text { Aktivitelerine Katılımları için Ekonomik Teşvikler } \\
\text { ve Promosyonlar Sunmalıdır? }\end{array}$ & 4 & 6 & 8 & 160 & 172 & 350 \\
\hline Konaklama İşletmelerinde Engellilere Özel & $(1.1)$ & (1.7) & (2.3) & (45.7) & $(49.1)$ & $(100.0)$ \\
\hline Tasarlan & 6 & 2 & 2 & 166 & 174 & 350 \\
\hline $\begin{array}{l}\text { Bu İssletmelerin Personelleri Engelli Bireylere } \\
\text { Yardımcı Olmak Konusunda İstekli Olmalıdır? }\end{array}$ & $(1.7)$ & $(0.6)$ & $(0.6)$ & $(47.4)$ & $(49.7)$ & $(100.0)$ \\
\hline $\begin{array}{l}\text { Konaklama İşletmeleri Engellilere Sundukları } \\
\text { Hizmetler Hakkında Eksiksiz Bilgilendirilmelidir? }\end{array}$ & 0 & (2.9) & $\begin{array}{c}8 \\
(2.3)\end{array}$ & $\begin{array}{c}118 \\
(33.7)\end{array}$ & $\begin{array}{c}214 \\
(61.1)\end{array}$ & $\begin{array}{c}350 \\
(100.0)\end{array}$ \\
\hline Konaklama İşletmelerinde Çalışan Personellerin & 4 & 2 & 8 & 134 & 202 & 350 \\
\hline $\begin{array}{l}\text { Engelli Bireylere Yardımcı Olmak Amacıyla Özel } \\
\text { Eğitimden Geçmeleri Gerekmektedir? }\end{array}$ & $(1.1)$ & $(0.6)$ & (2.3) & $(38.3)$ & $(57.7)$ & $(100.0)$ \\
\hline $\begin{array}{l}\text { İşletmelerin Barındırdığı Odaların Teçhizatı ve } \\
\text { Standardı Engelli Bireylere Uygun Olmalıdır? }\end{array}$ & $\begin{array}{c}2 \\
(0.6)\end{array}$ & $\begin{array}{c}2 \\
(0.6)\end{array}$ & $\begin{array}{c}8 \\
(2.3)\end{array}$ & $\begin{array}{c}130 \\
(37.1)\end{array}$ & $\begin{array}{c}208 \\
(59.4)\end{array}$ & $\begin{array}{c}350 \\
(100.0)\end{array}$ \\
\hline $\begin{array}{l}\text { İşletmelerin Sosyal Kullanım Alanları ve Ergonomik } \\
\text { Koşulları Engellilere Uygun Olmalıdır? }\end{array}$ & $\begin{array}{c}4 \\
(1.1)\end{array}$ & $\begin{array}{c}6 \\
(1.7)\end{array}$ & $\begin{array}{c}10 \\
(2.9)\end{array}$ & $\begin{array}{c}128 \\
(36.6)\end{array}$ & $\begin{array}{c}202 \\
(57.7)\end{array}$ & $\begin{array}{c}350 \\
(100.0)\end{array}$ \\
\hline $\begin{array}{l}\text { Odalarda Refakatçi ile Birlikte Konaklamaya } \\
\text { Olanak Göstermelidir? }\end{array}$ & $\begin{array}{c}4 \\
(0.6)\end{array}$ & $\begin{array}{c}2 \\
(0.6)\end{array}$ & $\begin{array}{c}2 \\
(0.6)\end{array}$ & $\begin{array}{c}136 \\
(37.7)\end{array}$ & $\begin{array}{c}210 \\
(60.0)\end{array}$ & $\begin{array}{c}350 \\
(100.0)\end{array}$ \\
\hline $\begin{array}{l}\text { Acil Durum Olasılı̆ında Eğitimli Personel Eşiğinde } \\
\text { Kalınacak Odanın veya Tesisin Tahliyesi ile İlgili } \\
\text { Gerekli Bilgilendirmeler Yapılmalıdır? }\end{array}$ & $\begin{array}{c}4 \\
(1.1)\end{array}$ & $\begin{array}{c}2 \\
(0.6)\end{array}$ & $\begin{array}{c}2 \\
(0.6)\end{array}$ & $\begin{array}{c}136 \\
(37.7)\end{array}$ & $\begin{array}{c}210 \\
(60.0)\end{array}$ & $\begin{array}{c}350 \\
(100.0)\end{array}$ \\
\hline $\begin{array}{l}\text { Konaklama İşletmeleri Engellilere Yönelik kali- teli } \\
\text { Hizmet Vermek Konusunda Duyarlı Olmalıdır? }\end{array}$ & $\begin{array}{c}2 \\
(0.6)\end{array}$ & $\begin{array}{c}4 \\
(1.1)\end{array}$ & $\begin{array}{c}2 \\
(0.6)\end{array}$ & $\begin{array}{c}122 \\
(34.9)\end{array}$ & $\begin{array}{c}220 \\
(62.9)\end{array}$ & $\begin{array}{c}350 \\
(100.0)\end{array}$ \\
\hline
\end{tabular}

$\mathrm{Bu}$ sorulara cevapların genellikle koşulların engellilere yönelik olmasına katılan kişilerin sayısının fazlalığı, işletmelerde engellilere yönelik eksikliklerin fazlalığına ve engellilerin ihtiyaç duyduklarının fazlalığına işaret etmektedir. Bunlara ilave olarak, Tablo 4'de, konaklama mekânlarındaki odaların engelli bireyler için refakatçi ile kalabilmelerine uygun olması gerektiğini \%60 kişi kesinlikle olması gerektiğini belirtirken, \%37 kişi ise uygun bir düşünce olduğunu ifade etmişlerdir. Acil durumlarda eğitimli personel eşliğinde kalınacak odanın veya tesisin tahliyesi ile ilgili gerekli bilgilendirmenin elzem olduğu düşüncesi yaklaşık \%98 civarında olduğu tespit edilmiştir. Eğitimli personelin önemi özellikle acil durumlarda daha fazla ön plana çıkmaktadır çünkü eğitimli personel acil durumlarda nasıl davranacağını daha iyi bilmektedir. 
Konaklama işletmelerinin engellilere yönelik olarak hizmet kalitesini arttırma konusunda daha hassasiyet bekleyen kişi sayısı 350 kişiden, hemen hemen tamamının (342) olumlu görüş verdiği, kalan 8 kişiden 4 tanesi katılmazken, 2 kişi kararsız, diğer 2 kişi ise kesinlikle bu düşünceye katılmadığı anlaşılmaktadır. Ayrıca, Tablo 4'deki engellilerin turizm işletmelerinden beklentilerine yönelik soruların frekans analizi sonuçlarının standart sapma ve ortalamalarına bakılmıştır. Buna göre, örneklem kapsamındaki engelli bireylerin beklenti düzeyi $X=4,57$ ortalaması olduğu, standart sapmanın ise 0,97 olarak tespit edilmiştir. Bu ortalamalara göre engelli bireylerin konaklama işletmelerinden beklentilerinin yüksek olduğu, mevcut durumda istenilen beklenti düzeyinde olmadığı söylenebilir.

\section{Engelli Bireylerin Turizm İşletmelerine Ait Kısım, Bölüm ve Özelliklerinin Mevcut Durumuna (Uygunluğuna) Yönelik Sorularının Frekans Analiz Sonuçları}

Araştırmanın bu bölümü, turizm işletmelerinin genel olarak yapılarının, özelliklerinin engelli bireyler için uygun olup olmadığını yani durum tespitini ortaya koyabilmek amacıyla katılımcılara yöneltilen soruların analizinden oluşmaktadır. Turizm işletmelerinin engelliler için uygun olup olmadığ sorulduğunda, \%30'u uygun bulmazken, oldukça uygun bulan \%4'dur ve çok düşük bir yüzdeliktedir. (1) Kesinlikle Uygun Değildi, (2) Uygun Değildi, (3) Kararsızım, (4) Uygundu, (5) Tamamen uygundu şeklinde alınmıştır.

Tablo 5. Engelli Bireylerin Turizm İşletmesinin Kısım, Bölüm ve Personel Özelliklerinin Mevcut Durumuna (Uygunluğuna) Yönelik Sorularının Frekans Analiz Sonuçları

\begin{tabular}{|c|c|c|c|c|c|c|}
\hline Sorular & $\begin{array}{c}\text { (1) } \\
\text { F / \% } \\
\end{array}$ & $\begin{array}{c}(2) \\
\text { F / \% } \\
\end{array}$ & $\begin{array}{c}(3) \\
\text { F / \% } \\
\end{array}$ & $\begin{array}{c}(4) \\
\text { F / \% } \\
\end{array}$ & $\begin{array}{c}(5) \\
\text { F / \% } \\
\end{array}$ & $\begin{array}{l}\text { Toplam } \\
\text { F / \% }\end{array}$ \\
\hline Personel Tutumu ile ilgili Soruya Verilen Yanitlar & 28 & 58 & 86 & 160 & 18 & 350 \\
\hline Deneyimli Personel Miktarı ile ilgili Soruya & $(8.0)$ & $(16.6)$ & $(24.6)$ & $(45.7)$ & $(5.1)$ & $(100.0)$ \\
\hline Verilen Yanitlar & 44 & 132 & 102 & 62 & 10 & 350 \\
\hline Resepsiyon Servisi ile ilgili Soruya Verilen Yanttlar & $(12.6)$ & $(37.7)$ & $(29.1)$ & $(17.7)$ & $(2.9)$ & $(100.0)$ \\
\hline Lobi Kabul Alanı Ergonomik Durumu ile ilgili & 42 & 86 & 100 & 110 & 12 & 350 \\
\hline Soruya Verilen Yanitlar & $(12.0)$ & $(24.6)$ & $(28.6)$ & $(31.4)$ & $(3.4)$ & $(100.0)$ \\
\hline Konaklama İşletmesi Girişi ile ilgili Soruya Verilen & 32 & 104 & 152 & 52 & 10 & 350 \\
\hline Yanitlar & $(9.1)$ & $(29.7)$ & $(43.4)$ & $(14.9)$ & $(2.9)$ & $(100.0)$ \\
\hline Otel tuvaletler ve Banyonun Durumu ile ilgili & 24 & 112 & 60 & 142 & 12 & 350 \\
\hline Soruya Verilen Yanitlar & $(6.9)$ & $(32.0)$ & $(17.1)$ & $(40.6)$ & $(3.4)$ & $(100.0)$ \\
\hline Odaların Konumları ile ilgili Soruya Verilen & 52 & 84 & 102 & 96 & 16 & 350 \\
\hline Yanitlar & $(14.9)$ & $(24.0)$ & $(29.1)$ & $(27.4)$ & $(4.6)$ & $(100.0)$ \\
\hline Kafe/Bar/Restoranlar ile ilgili Soruya Verilen & 32 & 112 & 118 & 76 & 12 & 350 \\
\hline Yanitlar & $(9.1)$ & $(32.0)$ & $(33.7)$ & $(21.7)$ & $(3.4)$ & $(100.0)$ \\
\hline \multirow[t]{2}{*}{ Asansörler ile ilgili Soruya Verilen Yanitlar } & 52 & 182 & 54 & 56 & 6 & 350 \\
\hline & $(14.9)$ & $(52.0)$ & $(15.4)$ & $(16.0)$ & $(1.7)$ & $(100.0)$ \\
\hline Merdiven ve Koridorlar ile ilgili Soruya Verilen & 56 & 96 & 62 & 112 & 24 & 350 \\
\hline Yanitlar & $(16.0)$ & $(27.4)$ & $(17.7)$ & $(32.0)$ & $(6.9)$ & $(100.0)$ \\
\hline \multirow[t]{4}{*}{ Gece Kulüpleri ile ilgili Soruya Verilen Yanıtlar } & 56 & 124 & 68 & 96 & 6 & 350 \\
\hline & $(16.0)$ & $(35.4)$ & $(19.4)$ & $(27.4)$ & $(1.79)$ & $(100.0)$ \\
\hline & 158 & 142 & 38 & 6 & 6 & 350 \\
\hline & $(45.1)$ & $(40.6)$ & $(10.9)$ & $(1.7)$ & $(1.7)$ & $(100.0)$ \\
\hline
\end{tabular}


Tablo 5'de engellilerin konaklama işletmelerinin kısım, bölüm ve personel özelliklerinin mevcut durum tespitine (uygunluğuna) yönelik sorularının frekans analiz sonuçlarına göre; personel tutumlarından genel olarak yarısı \%45,7'lik kısım memnun iken, \%24,6'lik kısım ise kararsız kaldığ 1 ifade edilmiştir. Deneyimli personel sayısı sorusuna ise \%37,7 ile yetersiz bulanlar ilk sırada yer alırken, \%29,1'i kararsız olduklarını belirtmişlerdir. Deneyimli personel sayısını yeterli bulan katılımcı sayısı ise 72 kişidir. Yine, Tablo 5'de resepsiyon hizmetini uygun bulan kişiler $\% 31,4$ ile ilk sırada yer alırken, kararsız olan kişiler \%28,6 ve uygun olmadığını, düşünenler ise \%24,6 ile takip etmektedir. Kararsız olan kişilerin sayısının bu kadar fazla olmasının nedeni bilgi eksikliğinden kaynaklanıyor olabilir. Konaklama işletmelerinin lobi alanlarının engelli bireyler için uygun olup olmadığına dair soruda, ilginç olarak \%42,4'u kararsız iken, \%29,7'si uygun olmadığını belirtmişlerdir. Bunlara ilave olarak Tablo 5 'de, konaklama yerlerinin girişine yönelik sorudan çoğunluk yani \%40,6'si memnun iken, \%32'si uygun görmemektedir. Bu soruda ankete katılanların beklentilerinin yüksek olduğu veya birçok işletmenin engellilere uygun olmadığını göstermektedir. Tuvaletler ve banyoların durumları ile ilgili analiz sonuçları göre, ilginç olarak \%29,1 kişi kararsızdır ve ilk sırada yer almaktadır. \%24 ile uygun olmadığını düşünen kişiler gelmektedir. Odaların konumları sorusuna ise, ankete katılanların yine kararsız olanlar ilk sırada yer alırken, benzer şekilde uygun olmadığını düşünen \%32'lik kesim da ikinci sırada yer almaktadır. Kafe ve restoranlarla ilgilidir ve çoğunluk kesim (\%52) kafe ve restoranları engellilere uygun bulmamaktadır. Ayrıca, Tablo 5'e göre Kafe/Bar/Restoranlar ile ilgili engellilerin verdikleri yanıtlar şöyledir. Uygun değildir diyenlerin sayısı \%52'lik bir oranla en yüksek seviyede iken, asansörlerden memnun olmayan engelli kişi sayısı ile memnun olan engelli kişi sayısı arasında çok fazla bir fark yoktur. Bunun nedeni engel türleri arasında farklılıklar bulunmasından kaynaklanıyor olabilir. Merdiven koridorların engellilere uygun olmadığını 62 kişi yani \%35,4'u düşünmektedir. Uygun olduğunu belirtenler ise sadece \%27,4 olarak gerçekleşmiştir. Son olarak ise gece kulüpleri ile ilgili soru sorulmuştur. Buna göre, $\% 45^{\prime}$ lik kısım gece kulüplerini engellilere kesinlikle uygun görmezken, \%40,6'lik kısım da aynı şekilde uygun olmadığını belirtmişlerdir. Tamamen uygundu diyenlerin sayısı oldukça düşüktür.

Tablo 6' de Engellilerin turizm işletmesinin sosyal, kültürel ve çevresel alan özelliklerinin mevcut durum tespitine (uygunluğuna) yönelik sorularının frekans analiz sonuçlarına göre; engellilerin otopark alanı durumu ile ilgili sorulara verilen yanıtlarda uygun diyenlerin sayısı \%36,6 iken uygun değildir diyenlerin sayısı \%42,9'dur. Buradan hareketle engel türleri arasındaki farklılığın bu eşitliği sağladığı söylenebilir. Sosyal alanlardaki yürüyüş yollarının engellilere uygun olmadığını belirten kişi sayısı 116 ve kesinlikle uygun değil diyen ise 82 dir. Ankete katılanların yarıdan fazlası bu soruya olumsuz cevap vermektedir. Uygun olduğunu düşünen sayı ise, sadece 68 kişidir. Plajların engellilere uygun olup olmadığı ile ilgili soru bulunmaktadır. Bu soruya ne yazık ki büyük bir kesim toplamda 294 kişi uygun olmadığını düşünmektedir. Plajları uygun gören kişi sayısı sadece 32 olmuştur. Yine Tablo 6'de, sosyal alanlardaki tuvaletlerin engelli bireyler için nasıl olduğu sorusuna \%35,4 ile uygun görmeyenler ilk sırada iken, \%23,4'u ise uygun görmektedir. Sauna, hamam ve yüzme havuzlarının uygunluğunun olmadığını büyük bir çoğunluğun (250 kişi) belirten engelli bireyler, bu tarz eğlence yerlerinin engellilere yönelik olmasını gerektiğini belirtmişlerdir. Konferans alanları hakkında pek bir fikri yok iken, uygun olmadığını düşünenlerin sayısı ise 116 kişi olmuştur. Başka bir ifadeyle \%33,1'lik kişi 'uygun değildi' derken, 'kesinlikle uygun değildi' diyenler \%17,7 olarak gerçekleşmiştir. Ayrıca, işletmelerin internet siteleri ile ilgili soru yöneltilmiştir ve sitelerin engellilere yönelik olmadığını düşünenler \%36,6 iken, uygundur diyenler \%24,6 ile ikinci sırada yer almaktadır. Egzersiz olanaklarını engelliler için kesinlikle uygun olmadığını belirtenler ve uygun değildi diyenler sırasıyla \%40,6 ve \%41,7'dir. Uygun olduğunu belirten kişi sayısı ise sadece 12 kişidir. Restoran ve kafelerdeki masalar arasını engelliler için rahat gidebilecek aralıkta olup olmadığı 
sorulduğunda, \%36,6 kişi uygun olmadığını belirtmişlerdir. \%21,1'i ise uygun olduğunu söylemişlerdir. Medikal görevli sayısının miktarını yetersiz bulanların toplamdaki sayısı 350 kişiden, 282 olmuştur. 52 kişi kararsız iken, $8+8$ kişi ise uygun olduğunu belirtmişlerdir. Son olarak, Şezlong miktarına yönelik bir soru sorulmuştur. Şezlong miktarı konusunda da olumsuz düşünen engelli bireylerin cevapları "kesinlikle uygun değildi" ve "uygun değildi" seklinde olmuştur. Şezlong Miktarı ve Düzeni ile ilgili soruya kesinlikle uygun değildi diye cevap verenlerin sayısı \% 49,7 olarak çoğunlukta olduğu tespit edilmiştir. Ayrıca, Tablo 5'de engellilerin turizm işletmesinin kısım, bölüm ve personel özelliklerinin engelliler uygunluğuna yönelik sorulara, Tablo 6'de ise engellilerin turizm işletmesinin sosyal, kültürel ve çevresel alan özelliklerinin engelliler uygunluğuna yönelik soruların frekans analizi sonuçlarının standart sapma ve ortalamalarına bakılmıştır. Buna göre, örneklem kapsamındaki engelli bireylerin uygun görme düzeyi $X=2,65$ ortalaması olduğu, standart sapmanın ise 1,15 olarak tespit edilmiştir. Bu ortalamalara göre engelli bireylerin mevcut konaklama işletmelerinin uygun olmadığı diğer bir ifadeyle konaklama işletmelerinin engelli bireylere göre yeterli düzeyde olmadığı söylenebilir. Tüm sorulara verilen ifadeler incelendiğinde yani 'beklenti' ve 'uygun görme' sorulara verilen cevapların örtüştüğü tespit edilmiştir.

Tablo 6. Engelli Bireylerin Turizm İşletmelerine Ait Sosyal, Kültürel ve Çevresel Alan Özelliklerinin Engelliler Uygunluğuna Yönelik Sorularının Frekans Analiz Sonuçları

\begin{tabular}{|c|c|c|c|c|c|c|}
\hline Sorular & $\begin{array}{c}(1) \\
F / \% \\
\end{array}$ & $\begin{array}{c}(2) \\
\mathrm{F} / \% \\
\end{array}$ & $\begin{array}{c}(3) \\
\mathrm{F} / \% \\
\end{array}$ & $\begin{array}{c}4) \\
\text { F / \% } \\
\end{array}$ & $\begin{array}{c}5) \\
F / \% \\
\end{array}$ & $\begin{array}{c}\text { Toplam } \\
\text { F / } \% \\
\end{array}$ \\
\hline Otopark Alanı Durumu ile ilgili Soruya Verilen & 42 & 108 & 72 & 114 & 14 & 350 \\
\hline Yanitlar & $(12.0)$ & (30.9) & (20.6) & (32.6) & $(4.0)$ & $(100.0)$ \\
\hline Sosyal Alanlardaki Yürüyüş Yolları ile ilgili & 82 & 116 & 66 & 68 & 18 & 350 \\
\hline Soruya Verilen Yanitlar & (23.4) & (33.1) & (18.9) & (19.4) & (5.1) & $(100.0)$ \\
\hline Plajlar ile ilgili Soruya Verilen Yanitlar & 162 & 132 & 24 & 20 & 12 & 350 \\
\hline Sosyal Alanlardaki Tuvaletler ile ilgili Soruya & (46.3) & (37.7) & (6.9) & (5.79) & (3.4) & $(100.0)$ \\
\hline Verilen Yanitlar & 66 & 124 & 66 & 82 & 12 & 350 \\
\hline Sauna/Hamam ve Yüzme Havuzu ile ilgili & (18.9) & (35.4) & (18.9) & (23.4) & (3.4) & $(100.0)$ \\
\hline Soruya Verilen Yanitlar & 112 & 138 & 74 & 14 & 12 & 350 \\
\hline Konferans Alanları ile ilgili Soruya Verilen & (32.0) & (39.4) & (21.1) & $(4.0)$ & (3.4) & $(100.0)$ \\
\hline Yanitlar & 62 & 116 & 148 & 16 & 8 & 350 \\
\hline İşletmenin/İşletmelerin Internet Sitesi ile ilgili & (17.7) & (33.1) & (42.3) & (4.6) & (2.3) & $(100.0)$ \\
\hline Soruya Verilen Yanitlar & 70 & 128 & 48 & 86 & 18 & 350 \\
\hline Egzersiz Olanakları ile ilgili Soruya Verilen & $(20.0)$ & (36.6) & (13.7) & (24.6) & (5.1) & $(100.0)$ \\
\hline Yanitlar & 142 & 146 & 50 & 4 & 8 & 350 \\
\hline Restoran/Kafelerdeki Masalar Arasındaki Geçiş & (40.6) & (41.7) & (14.3) & (1.1) & (2.3) & $(100.0)$ \\
\hline Alanları ile ilgili Soruya Verilen Yantlar & 60 & 128 & 82 & 74 & 6 & 350 \\
\hline Medikal Görevli Miktarı ile ilgili Soruya Verilen & (17.1) & (36.6) & (23.4) & (21.1) & (1.7) & $(100.0)$ \\
\hline Yanitlar & 136 & 146 & 52 & 8 & 8 & 350 \\
\hline Şezlong Miktarı ve Düzeni ile ilgili Soruya & (38.9) & (41.7) & (14.9) & (2.3) & (2.3) & (100) \\
\hline Verilen Yantlar & 174 & 116 & 40 & 12 & 8 & 350 \\
\hline & $(49.7)$ & (33.1) & (11.4) & (3.4) & (2.3) & (100) \\
\hline
\end{tabular}

Cinsiyet, Yaş, Eğitim Durumları ile Engelli Bireylerin Turizm İşletmelerinden Beklenti ve mevcut durum (Uygunluk) Görüşlerine Yönelik Farklılığını Ölçmek Amacıyla Yapılan Analiz Sonuçları

Araştırma kapsamında örnekleme dâhil engelli bireylerin konaklama işletmelerinden beklentileri ve uygun (sorunlar) görme görüşlerinin genel ortalaması alınmıştır. Burada amaç, konaklama 
işletmelerine yönelik tutum ve görüşlerinin tespitine yönelik bir ipucu sağlamaktır. Bu değerler kapsamında araştırmada cinsiyet, yaş ve eğitim durumlarına göre verilen ifadelerde farklılık olup olmadı ̆̆ diğere bir ifadeyle anlamlı olup olmadı $\breve{g} 1$ test edilmiştir. Bu test için nonparametrik analizlerden Many-Whitney U testinden yararlanılmıştır. Analiz sonuçları aşağıda Tablo 6 ve tablo 7 'de verilmiştir.

Tablo 7. Cinsiyet, Yaş ve Eğitim Durumları ile Engelli Bireylerin Konaklama İşletmelerinden Beklentilerine Yönelik Farklılığını Ölçmek Amacıyla Yapılan Mann Whitney U Testi Analiz Sonuçları

Tablo 7'de Cinsiyet, yaş ve eğitim Durumları ile engelli bireylerin konaklama işletmelerinden beklenti görüşlerine yönelik farklılığını ölçmek amacıyla Mann Whitney U Testi yapılmıştır. Mann-Whitney U Testi sonucuna göre; verilen cevaplar açısından kadın ile erkekler arasında $(U=102,7 ; p=0,14 ; p>0,05)$, yaş grupları arasında $(U=169,1 ; p=0,18 ; p>0,05)$ ve eğitim durumları arasında vermiş oldukları ifadelere yönelik ( $\mathrm{U}=276,3 ; \mathrm{p}=0,69 ; \mathrm{p}>0,05)$, anlamlı bir farklılık olmadığı tespit edilmiştir. Bunun anlamı, katılımcıların konaklama işletmelerinden beklentilerinin ortak olduğu söylenebilir.

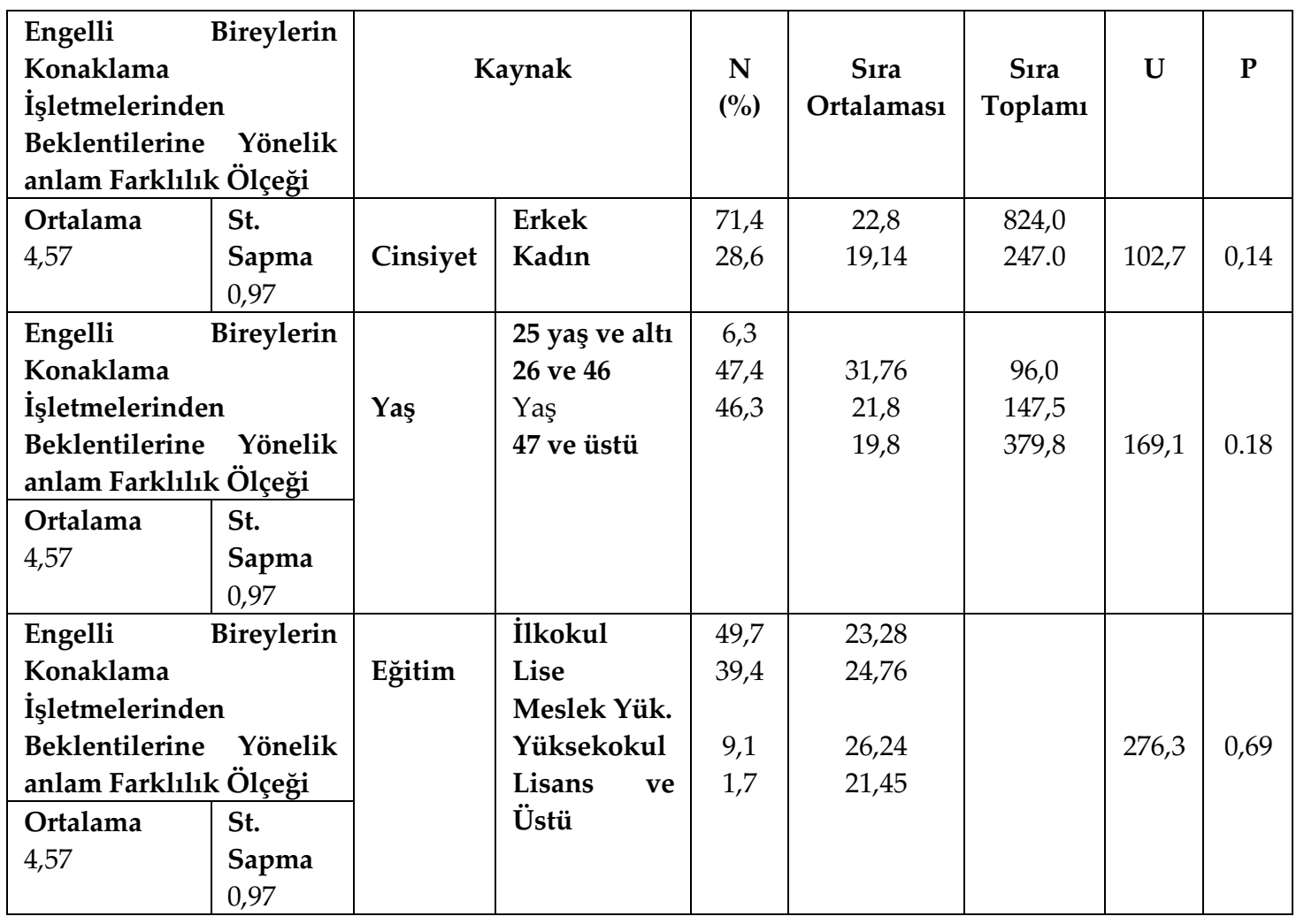

Tablo 8'de Cinsiyet, yaş ve eğitim Durumları ile engelli bireylerin konaklama işletmelerinin uygunluğuna (sorunlar) yönelik görüşlerinde farklılık olup olmadığını ölçmek amacıyla Mann Whitney U Testi yapılmıştır. Mann-Whitney U Testi sonucuna göre; verilen cevaplar açısından kadın ile erkekler arasında $(U=246,7 ; p=0,37 ; p>0,05)$, yaş grupları arasında $(U=457,9 ; p=0,43$; $p>0,05)$ ve eğitim durumları arasında $(U=189,3 ; p=0,19 ; p>0,05)$, anlamlı bir farklılık olmadığ 
tespit edilmiştir. Bunun anlamı, katılımcıların konaklama işletmelerinin mevcut durumlarının engelli bireylere turizme katılımı bağlamında sorun teşkil ettiğini ve uygunluğun yeterli olmadığı söylenebilir.

Tablo 8. Cinsiyet, Yaş ve Eğitim Durumları ile Engelli Bireylerin Konaklama İşletmelerinin mevcut durum (Uygunluk) Görüşlerine Yönelik Farklılığını Ölçmek Amacıyla Yapılan Mann Witney U Testi Analiz Sonuçları

\begin{tabular}{|c|c|c|c|c|c|c|c|}
\hline $\begin{array}{lr}\text { Engelli } & \text { bireylerin } \\
\text { konaklama işletmelerinin } \\
\text { uygunluk görüslerine } \\
\text { yönelik anlam farklılık } \\
\text { ölçeği }\end{array}$ & \multicolumn{2}{|c|}{ Kaynak } & $\begin{array}{c}N \\
(\%)\end{array}$ & $\begin{array}{c}\text { Sira } \\
\text { Ortalaması }\end{array}$ & $\begin{array}{c}\text { Sira } \\
\text { Topla } \\
\text { m1 }\end{array}$ & U & $\mathbf{P}$ \\
\hline \begin{tabular}{l|l} 
Ortalama & St. \\
2,65 & Sapma \\
& 1,15 \\
\end{tabular} & $\begin{array}{l}\text { Cinsiye } \\
t\end{array}$ & $\begin{array}{l}\text { Erkek } \\
\text { Kadın }\end{array}$ & $\begin{array}{l}71,4 \\
28,6\end{array}$ & $\begin{array}{c}32,8 \\
24,14\end{array}$ & $\begin{array}{l}634,0 \\
357.0\end{array}$ & 246,7 & 0,37 \\
\hline $\begin{array}{lr}\text { Engelli } & \text { bireylerin } \\
\text { konaklama } & \text { işletmelerinin } \\
\text { uygunluk görüşlerine } \\
\text { yönelik anlam farklılık } \\
\text { ölçeği }\end{array}$ & Yaş & $\begin{array}{l}25 \text { yaş ve altı } \\
26 \text { ve } 46 \\
\text { Yaş } \\
47 \text { ve üstü }\end{array}$ & $\begin{array}{l}6,3 \\
47,4 \\
46,3\end{array}$ & $\begin{array}{l}43,76 \\
31,8 \\
39,1\end{array}$ & $\begin{array}{l}117,0 \\
187,5 \\
279,8\end{array}$ & 457,9 & 0.43 \\
\hline \begin{tabular}{l|l} 
Ortalama & St. \\
2,65 & Sapma \\
& 1,15 \\
\end{tabular} & & & & & & & \\
\hline $\begin{array}{lr}\text { Engelli } & \text { bireylerin } \\
\text { konaklama işletmelerinin } \\
\text { uygunluk görüslerine } \\
\text { yönelik anlam farklılık } \\
\text { ölçeği }\end{array}$ & Eğitim & $\begin{array}{l}\text { İlkokul } \\
\text { Lise } \\
\text { Meslek Yük. } \\
\text { Yüksekokul } \\
\text { Lisans ve }\end{array}$ & $\begin{array}{l}49,7 \\
39,4 \\
\\
9,1 \\
1,7\end{array}$ & $\begin{array}{l}23,28 \\
24,76 \\
\\
26,24 \\
21,45\end{array}$ & $\begin{array}{l}453,5 \\
245,6 \\
189,3 \\
559,3\end{array}$ & 189,3 & 0,19 \\
\hline \begin{tabular}{l|l} 
Ortalama & St. \\
2,65 & Sapma \\
& 1,15
\end{tabular} & & Üstü & & & & & \\
\hline
\end{tabular}

Araştırmada genel olarak, frekans analiz sonuçları değerlendirildiğinde, konaklama işletmeleri hakkında engelli bireyler olumsuz düşünmektedir. Konaklama işletmenin yapısı, hizmetleri, teçhizatı konusunda memnuniyet derecelerinin düşük olduğu görülürken, ilk etapta sorulan sorularda ise, engellilerin konaklama işletmelerinden beklentilerinin oldukça fazla olduğu sonucuna varılmıştır. Ayrıca, bazı demografik değişkenler ile engelli bireylerin konaklama işletmelerinin uygunluğuna (sorunlar) yönelik görüşlerinde farklılık olup olmadığını ölçmek amacıyla Mann Whitney U Testi yapılmış, çıkan sonuçta anlamlı bir farklılık olmadığı tespit edilmiştir. Bunun anlamı, katılımcıların konaklama işletmelerinin mevcut durumlarının engelli bireylere turizme katılımı bağlamında sorun teşkil ettiğini ve uygunluğun yeterli olmadığ söylenebilir.

\section{SONUÇ ve ÖNERILER}

Genel olarak, araştırma kapsamında frekans analiz sonuçları değerlendirildiğinde, turizm merkezleri ve işletmeleri hakkında engelli bireyler olumsuz düşünmektedir. Konaklama 
işletmelerinin yapısı, hizmetleri, teçhizatı konusunda memnuniyet derecelerinin düşük olduğu görülürken, ilk etapta sorulan sorularda ise, engellilerin konaklama işletmelerinden beklentilerinin oldukça yüksek olduğu sonucu tespit edilmiştir. Engelli bireylerin seyahat ve turizme katılma niyetleri olsa da turizm hareketlerine katılım düzeylerinin düşük seviyede olduğu anlaşılmıştır. Bu, doğrudan veya dolaylı psikolojik nedenlerde de yatmakta olabilecek bir durumdur. Ayrıca, araştırma da tespit edilen diğer bir sonuç, bütünün ve kültürün bir parçası olan İstanbul ilinde binlerce engelli birey ayn zamanda binlerce engele takılmakta ve sosyokültürel alanlarda ve konaklama işletmelerinde yeterli düzeyde donanım bulunamamakta, bulunsa dahi kendisini özgür, ergonomik, erişebilir, ulaşabilir ya da bütünün içinde hissedememektedir. Oysaki herkes için özgür, sağlıklı, mutlu, başarılı ve verimli bir yaşam hayatımızda çok büyük bir öneme sahiptir. Ülkemizin en kalabalık ve dünyanın birçok ülkesinden fazla nüfusuna sahip olan İstanbul kentinde binlerce engelli birey yaşamasına rağmen, oranlar incelendiğinde engellilerin beklentilerinin karşılanma oranı çok düşük düzeyde olduğu gözlemlenmiştir. Bu durum dolayısıyla her yıl milyonlarca turiste ve bunun içinde hareket kısıtlılığı yaşayan bireylere ev sahipliği yapan kent için erişilebilir, ulaşılabilir ve kapsayıcı yaşam alanları başta yöneticiler olmak üzere, tasarımcıların ve ev sahipliği yapan toplumun dikkat etmesi gereken önemli hususlarıdır.

Farklı toplumların ortak engelleri bulunmaktadır. Bu engeller hareket kısıtlılığı yaşayan bireyleridir. Bu bağlamda engelli bireyler için ortak çözüm önerileri geliştirilebilir ve evrensel tasarımlar yapılarak, yaşlı, engelli insan, normal insan, toplum, kent, ülke vb. ayırmaksızın bütün olunabilir. Ancak bu sayede tüm engellerin ortadan kalkması mümkündür. Birbirinden çok farklı bireylere ev sahipliği yapan ve turizmin kalbi olan şehirler içinde yaşamakta olan toplumdan, yöneticilere, kamusal alanlara etki eden sivil toplum kuruluşlarına kadar herkesin başlıca görevleri bulunmaktadır.

Sonuç olarak, yapılan bu araştırma ile geçici veya daimi engellilik ile yaşamak zorunda kalan bireylerin eşit ve onurlu bir şekilde turizm faaliyetlerine katılmaları için katılımcıların görüşleri doğrultusunda öneriler sunulmuştur. Engelli bireylerin önünde başta ekonomik, fiziksel (genel alanlar, yapı iç ve dış mekânları) ve ulaştırma ile ilgili sorunlar bulunmaktadır. Bu çalışmada, belirtilen sorunları ortadan kaldırmaya yönelik aşağıda belirtilen öneriler geliştirilmiştir. Getirilen bu önerilerin yerine getirilmesi için devlet (kamu kurumları), sivil toplum örgütleri, yerel yönetimler, özel sektör, uzmanlar, engelli insanlar ve aileleri, toplum ve medyanın işbirliği ve eşgüdüm içerisinde olmaları gerekmektedir. Engelli bireylerin konaklama işletmelerinden beklentileri ve yapılan öneriler şu şekilde sıralanabilir.

- Her bir engel türü ve derecesi düşünülerek işletmeler yeniden yapılandırılmalıdır.

- Engelli bireyler için konaklama tesislerinde düzenlemeler yapılırken engellilerin görüşleri alınarak bu düzenlemelerin yapılması gerekmektedir.

- Otel içi ve dışında genel alanlarda uyarıcı levha ve işaret sisteminin engeliler içinde düzenlenmiş olması gerekmektedir.

- Konaklama işletmelerinin, bölümleri, odaları, asansörleri tuvaletleri ve banyoları ile tüm yaşam yerleri engelli bireyleri düşünerek dizayn edilmesi gerekmektedir.

- Konaklama tesislerinde bulunan engelli odası sayısının toplam oda sayısının \%1'i oranında değil, daha fazla sayıda olması gerekmektedir,

- Engellilerin sosyal yönleri ve hassasiyetleri düşünülerek belirli zamanlarda yapılan anketlerle memnuniyet seviyeleri ölçülmelidir ve bu ölçüm oranında esnek bir yönetim anlayışı benimsenerek gerekli değişiklikler hemen uygulamaya konulmalıdır. 
- Devletten ve özel kuruluşlardan gerekli finansal destek sağlanıp özel eğitimin sadece okullarda değil her turizm işletmesinde bir uzman desteği ile çalışmaların planlı bir şekilde yürütülmesi gerekir.

- Engellilerin sadece temel ihtiyaçları gözetilmemeli sosyal ihtiyaçları da göz önünde bulundurularak toplumla senkronizasyonu sağlanmalıdır.

- Turizm sektöründe çalışanların doğru iletişim ve yaklaşım yöntemlerini öğrenmesi gerekmektedir.

- Turizm endüstrisinde bulunan ve her kesimin eğitimi almaları gerekmektedir.

- Ortopedik engelliler, görme, işitme ve konuşma engelliler ile otizmli ve farklı gelişen bireylerin otellerin ve turizm tesislerinden yararlanabilmeleri için mimari erişilebilirlik düzenlemelerinin gerekliliği olmalı ve herkes için tasarım ilkesi benimsenmelidir.

- Engellilik ve engelli insanlar hakkında toplumsal bilinç oluşturulmalıdır. Okullarda ve medyada bilinçlendirici, eğitici ve öğretici empati kurmaya yönelik çalışmalar yapılmalıdır.

- Tüm tesisler her vatandaşın eşit şekilde yararlanabileceği bir tasarıma sahip olması gerekir. Burada mimarlara ve inşaat mühendislerine büyük görevler düşüyor. Yasaların getirdiği gereklilikleri hayata geçirmek onların sorumluluğundadır.

- Turizm faaliyetlerine katılabilmek için mutlaka bir ulaşım sistemine dâhil olmak gerekmekte olduğu hususu göz önüne alınarak, engelli misafirler için ulaştırma araçlarının varlığının sağlanması gerekir.

- Tatil destinasyonu olarak, seçilmekte olan engellilerin kullanabileceği şekilde toplu ulaşım araçlarının bulundurulması önemlidir.

- Engellilerin gittikleri tatil destinasyonundaki görülmeye değer yerlerin engellilere uygun şekilde dizayn edilmesi gerekmektedir.

- Bazı seyahat acentelerinin sadece engellilere yönelik tur programları düzenleyerek bu alanda uzmanlaşmaları önemlidir.

- Engelli misafirlerin, seyahatleri ile ilgili onu her türlü bilgiye (özellikle tanıtım araçlarında yer alan, engellilerin elde edebileceği hizmet ile olanaklar ile ilgili bilgiye) uygun semboller kullanılarak kolaylıkla erişimlerinin sağlanması gerekmektedir.

- Engelli misafirlerin bulundukları tatil destinasyonu ile ilgili görüşlerinin alınması ve varsa eksikliklerinin giderilmesine dikkat edilmelidir.

- Son olarak, engellilere verilen ek hizmetler için haksiz yere ücret talep edilmemesi ve zorunlu indirimlerin uygulanması gerekmektedir.

Uluslararası kaynaklarda, bu konuyla ilgili çok sayıda çalışmaya rastlanmakla birlikte ulusal alanda yapılmış sınırlı sayıda çalışmaya rastlanması da bu konuda bilimsel yayınların yapılmasının gerekliliğini düşündürmüştür. Engelli bireylerin erişebilir ve ulaşılabilir turizmin turizm endüstrisi içerisinde önemli bir paya sahip olabilmesi için yapılacak olan nitel ve nicel araştırmaların çok yönlü ve kapsamlı olarak ele alınması gerekmektedir. İstanbul ilinde yapılan bu çalışmanın, bu konuda yapılacak sonraki nitel çalışmalara bir kaynak olabileceği, bu alanda yapılacak olan bilimsel nicel araştırmalara katkı sağlayacağı ve engelli bireylerin turizm faaliyetlerine katılımı önündeki sorunların ortadan kaldırılmasına yönelik çalışmalara ışık tutacağ 1 düşünülmektedir. 


\section{KAYNAKÇA}

Akat, Ö. (2008). Pazarlama ă̆ırlıklı turizm işletmeciliği. Bursa: Ekin Yayınevi.

Artar, Y., Karabacakoğlu, Ç. (2003). Ortez ve tekerlekli sandalyenin üretimi, standartları ve pazar potansiyeli, (özürlülerin toplumsal gelişimine yönelik proje). Ankara: Milli prodüktivite merkezi.

Artar, Y. V. (2003). Türkiye'de Özürlüler Turizminin Geliştirilmesine Yönelik Olarak Konaklama Tesislerindeki Altyapı Olanaklarının Araştııılması. Ankara: Milli Prodüktivite Merkezi.: Basılmamış Uzmanlık Tezi.

Akıncı, Z. ve Sönmez N. (2015), Engelli Bireylerin Erişilebilir Turizm Beklentilerinin Değerlendirilmesine Yönelik Nitel Bir Araştırma, Anatolia: Turizm Araştırmaları Dergisi, 1(2):97113.

Aslan, M. ve Şeker, S. (2011). Engellilere Yönelik Toplumsal Algı ve Dışlanmışlık (Siirt Örneği), Sosyal Haklar Uluslararası Sempozyumu, Kocaeli: Petrol-İş Yayını, 449-463.

Ayyıldız, T. A. (2014). Konaklama İşletmelerinin Engelliler İçin Olanakları ve Yöneticilerin Görüşleri: Kuşadası Örneği. Gazi Üniversitesi Turizm Fakültesi Dergisi, 2: 84-100.

Buhalis, D. And Michopoulou, E., (2010). Information-Enabled Tourism Destination Marketing: Addressing the Accessibility Market. Current Issues in Tourism, 1(1): 1-24.

Bulgan, G. (2014). Engelli Turizmi: Antalya İlindeki Dört ve Beş Yıldızlı Otel İşletmelerinde Bir Araştırma. Isparta: Doktora Tezi, Süleyman Demirel Üniversitesi Sosyal Bilimler Enstitüsü İşletme Anabilim Dalı.

Burcu, E. (2007). Türkiye'de Özürlü Birey Olma Temel Sosyolojik Özellikleri ve Sorunları Üzerine Bir Araştırma. Ankara: Hacettepe Üniversitesi Yayınları.

Coşkun, M. K. (2010). Engellilere Yönelik Hizmetler: Amasya Örneği. Yüksek Lisans Tezi: Cumhuriyet Üniversitesi Sosyal Bilimler Enstitüsü, Sosyoloji Anabilim Dalı/Uygulamalı Sosyoloji Bilim Dalı.

Çakan, P. ve Sezer, Ö. (2010) Süreğen Hastalı̆̆ı Olan Çocuklara Sahip Annelerin Tutumları Kayg1 Düzeyleri ve Diğer Değişkenlerin İncelenmesi, Fırat Üniversitesi Sosyal Bilimler Dergisi,20 (2):1-28.

Davies, T. V. (1994). Accessible Design for Hospitality. Newyork: Mcgraw-Hill Inc.

Kalaycı, Ş. (2009). SPSS Uygulamalı Çok Değişkenli İstatistik Teknikleri, Ankara: Asil Yayınları

Ketboğa, S. (2016). İstanbul İli Örneğinde Otel İşletmelerinin Ab Erişilebilirlik Standartlarına Uygunluğunun Karşılaştırmalı Analizi. Yüksek Lisans Tezi, İstanbul Üniversitesi.

Kline, R. (2011), Principles and Practice of Structural Equation Modeling, New York: The Guilford Press.

Öngören, B. Atalay A., ve Tan, Ö., (2007). Muğla Özürlü Programı, Muğla: Muğla İl Sağlık Müdürlüğü Yayını.

Ören, K., (2003). Zihinsel Engellilerin İstihdam Sorunu ve Dengeleyici Tedbirler. Mali Çözüm Dergisi, 65, 126-139.

Özsoy, Y. Ö. (1998). Özel Eğitime Muhtaç Çocuklar Özel Eğitime Giriş. Ankara: Karatepe Yay. 9.Baskı.

Öztürk, M. (2011). Türkiye'de Engelli Gerçeği. İstanbul: Müsiad Cep Kitapları: 30. 
Popie, M. (2014). Paving the way to accessible tourism on the example of Krakow, European Journal of Tourism. Hospitality and Recreation, Special Issue, 55-71.

Seyyar, A. (2006). Özürlülere Adanmış Sosyal Politika Yazıları. Adapazarı: Adapazarı Büyükşehir Belediyesi.

Subaşığlu, F. (2008). Üniversitelerin Bilgi ve Belge Yönetimi Bölümlerinin Engellilik Farkındalığ Üzerine Bir Araştırma, Bilgi Dünyası, 2.399-430.

Sezgin, M. ve Ünüsan, Ç. (2004). Turizm Pazarlaması, Atlas Kitabevi, Konya.

Şahin, H. (2012). Engelli Bireylerin Konaklama Tesislerinden Memnuniyet Durumlarının İncelenmesi. Doktora Tezi: Hacettepe Üniversitesi Sosyal Bilimler Enstitüsü, Aile ve Tüketici Bilimleri Anabilim Dalı.

T.C. (21.06.2005). Resmi Gazete. T.C. Resmi Gazete: http://www.resmigazete.gov.tr/ eskiler/2005/06/20050621-11.htm adresinden alınd1

T.C. Resmi Gazete. (03.05.2013), Resmi Gazete Sayı: 28636: http://www.resmigazete.Gov.Tr/ Eskiler/2013/05/20130503-1.Htm adresinden alınd1

Tozlu E., ve Atay L. (2011). Engelli turizmine yönelik destinasyon ürün kapasitesi: Gelibolu yarımadası örneği. 12. Ulusal Turizm Kongresi, 30 Kasım-4 Aralık.

Türsab, (2008). Dünyada ve Türkiye'de Engelsiz Turizm Pazarı. Türsab Ar-Ge Departmanı Raporu.

Westcott, J. (2004). Improving Information on Accessible Tourism for Disabled People. Italy: European Commission.

Yau, M. K. (2004). Travelling with Disability More Than an Access Issue, Annals of Tourism Research, 2(3): 1-35.

Yaylı, A., ve Öztürk, Y., (2006). Konaklama İşletmeleri Yöneticilerinin Bedensel Engelliler Pazarına Bakış Açıları Üzerine Bir Araştırma. Gazi Üniversitesi Ticaret ve Turizm Eğitim Fakültesi Dergisi, 2(1):87-97.

Zengin, B. V. (2013). Bodrum Destinasyonunda Engelli Turizm Pazarının Değerlendirilmesi, International Journal of Economic And Administrative Studies, 6(11), 52-74.

www.TUiK, gov.tr, (2010). 